\title{
Efektivitas Model Problem Based Learning (PBL) terhadap Problem Solving Skill dan Penguasaan Konsep Kalor
}

\author{
Chrislay Agung Sarmatheo ${ }^{1 *}$, Muliati Syam ${ }^{2}$, dan Zulkarnaen ${ }^{3}$ \\ $1,2,3^{*}$ Program Studi Pendidikan Fisika, Fakultas Keguruan dan Ilmu Pendidikan, Universitas Mulawarman, Jalan \\ Muara Pahu Kampus Gn. Kelua \\ *E-mail: chrislaya25@mail.com
}

\begin{abstract}
Abstrak
Penelitian ini bertujuan untuk mengetahui efektivitas model Problem Based Learning terhadap Problem Solving Skill dan Penguasaan Konsep siswa pada materi Kalor. Jenis penelitian adalah penelitian kuantitatif yang dilakukan di SMA Negeri 8 Samarinda dengan populasi yaitu siswa kelas XI MIPA sebanyak 175 siswa. Teknik pengambilan sampel penelitian menggunakan purposive sampling dimana peneliti menentukan secara khusus sampel penelitian.Sampel penelitian yaitu siswa XI-MIPA-3 sebanyak 36 siswa. Teknik pengumpulan data menggunakan teknik tes esai dengan jumlah 20 soal. Efektivitas Model Problem Based Learning terhadap Problem Solving Skill siswa terlihat pada nilai uji-t yang sangat signifikan sebesar 12,275, sehingga Model Problem Based Learning efektif terhadap Problem Solving Skill Siswa. Efektivitas Model Problem Based Learning terhadap Penguasaan Konsep siswa terlihat pada nilai uji-t yang sangat signifikan sebesar 13,036, sehingga Model Problem Based Learning efektif terhadap Penguasaan Konsep Siswa.
\end{abstract}

Kata kunci: Problem Based Learning, Problem Solving Skill, Penguasaan Konsep

\begin{abstract}
This study aims to determine the effectiveness of Problem Based Learning models for Problem Solving Skill and Mastery of students' Concepts in the Heat. This type of research is quantitative research conducted at SMA Negeri 8 Samarinda with a population of 175 students in MIPA class. The research sampling technique used purposive sampling where the researcher specifically determined the research sample. The research sample consisted of 36 XI-MIPA-3 students. Data collection techniques using essay test techniques with a total of 20 questions. The effectiveness of the Problem Based Learning on the Problem Solving Skills of student's can be seen in the t-test value which is very significant at 12,275 , so that the Problem Based Learning is effective against the Problem Solving Skill of Students. The effectiveness of the Problem Based Learning on students Mastery of Concepts can be seen in the t-test value which is very significant at 13,036 , so that the Problem Based Learning is effective on the Mastery of Student Concepts.
\end{abstract}

Keywords: Problem Based Learning, Problem Solving Skill, Concept Mastery

Article History: Received: 20 Juli 2020

Accepted: 1 September 2020
Revised : 14 Oktober 2020

Published: 20 November 2020

How to cite: Sarmatheo, C. A., Syam, M., Zulkarnaen (2020). Efektivitas Model Problem Based Learning (PBL) terhadap Problem Solving Skill dan Penguasaan Konsep Kalor, 1(2). pp. 165 - 173. Retrieved from http://jurnal.fkip.unmul.ac.id/index.php/JLPF

Copyright (c) November 2020, Jurnal Literasi Pendidikan Fisika 
Efektivitas Model Problem....

\section{PENDAHULUAN}

Fisika merupakan suatu cabang ilmu yang erat kaitannya dengan kondisi sesungguhnya, kondisi alami atau dengan kata lain fenomena asli yang terjadi dalam kehidupan sehari-hari sehingga secara umum pembelajaran fisika tentunya memberikan suatu permasalahan yang dapat diselesaikan. Permasalahan inilah yang akan menjadi suatu pertanyaan terhadap siswa yang kemudian akan menjadi syarat dalam memberikan nilai pada siswa. Nilai dari pembelajaran fisika yang bersifat pasti inilah yang akan menjadi tolak ukur keberhasilan bagi siswa maupun guru dalam pembelajaran fisika.

Kabil (2015) pada penelitiannya dalam dunia pendidikan mengemukakan bahwa masalah yang paling dikeluhkan oleh siswa adalah siswa gagal dan kesulitan memahami pelajaran fisika. Keluhan itu diberikan karena memang pelajaran fisika itu kurang dapat dimengerti bagi siswa. Redish (Kabil, 2015) kembali menyatakan bahwa peneliti/pengajar sering terkejut dengan bagaimana siswa lebih sedikit tahu mengenai pembelajaran matematika namun kinerja di kelas matematika menunjukkan hasil yang baik. Dengan kata lain, masalah fisika tidak seperti matematika dan siswa tidak dapat memecahkan masalah fisika seperti memecahkan masalah yang murni matematis. Kesulitan siswa dalam memecahkan masalah fisika tersebut dapat ditunjukan dengan tes hasil belajar siswa pada mata pelajaran fisika.

Peneliti sebelumnya melakukan praktek lapangan persekolahan yang dilakukan di SMAN 8 Samarinda dan mengamati proses pembelajaran fisika yang dilakukan khususnya di kelas XI-MIPA 3. Peneliti mengamati bawha masih terdapat kendala pada pembelajaran seperti guru yang menyajikan materi secara teoritik dan abstrak sedangkan siswa tetap pasif, siswa hanya mendengarkan ceramah materi guru di depan kelas. Selain itu, waktu belajar siswa sebagian besar dipergunakan untuk mengerjakan buku tugas, mendengarkan ceramah, dan mengisi latihan melalui serangkaian kerja individual.

Peneliti kemudian menemukan bahwa hasil pembelajaran tersebut mengakibatkan hasil belajar siswa yang rendah. Peneliti kemudian mempelajari bahwa ada beberapa faktor yang mengakibatkan hasil belajar fisika siswa rendah yaitu penguasaan konsep siswa dan Problem Solving Skill siswa

Pada penelitiannya, Virgana (2017) menyatakan penguasaan konsep fisika dalam diri yang sedang belajar merupakan kemampuan dari seseorang untuk mengembangkan fakta yang satu dengan fakta lain. Seseorang dikatakan menguasai konsep fisika apabila orang tersebut mengerti benar konsep fisika yang dipelajarinya sehingga mampu menjelaskan dengan menggunakan kata-kata sendiri sesuai dengan pengetahuan yang dimilikinya.

Dalam penelitian Coşkun (2014), menemukan bahwa Problem Solving Skill terdiri dari proses definisi masalah, pengumpulan informasi mengenai masalah, menentukan hambatan yang dapat mencegah solusi dari masalah yang ada, dan motivasi terhadap perilaku pemecahan masalah. Karabacak (2015) dalam penelitiannya, menyatakan bahwa Problem Solving Skill adalah tindakan untuk memecahkan masalah atau proses yang memanfaatkan matematika dan sains untuk mengatasi masalah, juga juga dapat didefinisikan sebagai metode untuk mencari solusi melalui langkah-langkah pemecahan masalah.

Pada penelitian Güneş (2015) Problem Solving adalah suatu tindakan yang memiliki berbagai macam proses mental dan keterampilan ketika mencapai kesimpulan yang benar. Seseorang dengan Problem Solving Skill tingkat lanjut dapat secara efektif menggunakan pengetahuan dan dapat dengan mudah memecahkan masalah yang dihadapi. Problem Solving Skill menurut Rahono (2014) memiliki keunggulan antara lain melatih siswa, memecahkan masalah yang dihadapi secara realistis, mengidentifikasi dan melakukan penyelidikan, menafsirkan dan mengevaluasi hasil pengamatan, merangsang perkembangan kemajuan berfikir siswa untuk menyelesaikan masalah yang dihadapi dengan tepat.

Keow (2015) mengemukakan pada penelitiannya, di era teknologi informasi ini, kemampuan berpikir dan Problem Solving Skill sangat penting bagi siswa untuk menguasai pengetahuan kelas dunia dan pembangunan bangsa. Selain itu, keterampilan ini juga penting bagi generasi muda dalam memecahkan masalah dan menghadapi tantangan. Ulusoy 
(2012) pada penelitiannya mengemukakan bahwa, memberikan siswa Problem Solving Skill merupakan salah satu tujuan utama dalam pendidikan. Terutama dalam program-program yang tergantung pada gerakan filosofis yang progresif dan rekonstruktif, meningkatkan keterampilan pemecahan masalah adalah tujuan utama pendidikan.

Berdasarkan latar belakang masalah dan teori penguasaan konsep dan Problem Solving Skill dari hasil penelitian yang dilakukan oleh peneliti lainnya, maka diperlukan adanya model pembelajaran yang dapat memberikan efektivitas pada penguasaan konsep fisika siswa dan Problem Solving Skill siswa. Melalui teori dan penelitian yang dilakukan beberapa peneliti tersebut, salah satu model pembelajaran yang dapat digunakan adalah model Problem Based Learning

Saragih (2014) menyatakan dalam penelitannya bahwa salah satu cara yang dapat meningkatkan kemampuan pemecahan masalah dan kreativitas siswa adalah Problem Based Learning (PBL). PBL adalah salah satu model pembelajaran inovatif yang dapat memberikan kondisi agar siswa aktif dan kreatif. Penelitian yang dilakukan oleh Phungsuk (2017:01) menyatakan bahwa Pembelajaran berbasis masalah $(P B L)$ adalah pembelajaran yang berpusat pada siswa dimana siswa belajar tentang subjek dengan mencoba menemukan solusi untuk masalah yang ada.

Uzunboylu (2014), dalam penelitian yang disiapkan pada topik yang signifikan, ditemukan bahwa Problem Based Learning dikembangkan untuk menghilangkan kekurangan dan kelemahan pengajaran tradisional. Elkhamoshi, (2011) dalam penelitian menemukan bahwa kelompok $P B L$ memiliki skor yang lebih tinggi dalam prestasi akademik, juga menemukan bahwa ada peningkatan dalam prestasi belajar siswa saat menggunakan model $P B L$.

Yew (2016) dalam penelitiannya menyatakan $P B L$ adalah pendekatan pembelajaran yang memungkinkan siswa untuk belajar sambil terlibat aktif dengan model mental untuk belajar, dan membentuk kebiasaan belajar mandiri melalui praktik dan refleksi. Selçuk (2010) mengklaim bahwa $P B L$ tidak hanya membantu siswa dalam memperoleh pengetahuan tetapi juga mengembangkan keterampilan pemecahan masalah mereka, berpikir kritis dan kreatif.

Melalui penelitian para peneliti yang telah dilakukan mengenai Problem Based Learning (PBL), maka Problem Based Learning (PBL) dapat menjadi solusi dalam mengatasi permasalahan mengenai Problem Solving Skills siswa yang berpengaruh terhadap hasil belajar siswa yang terlihat melalui tes penguasaan konsep siswa. Gurses, Dogar, dan Geyik (2017) melakukan penelitian menerapkan model Problem Based Learning pada pembelajaran Entalpi dan didapatkan perbedaan yang signifikan sebelum dan sesudah model Problem Based Learning digunakan. Ersoy dan Başer (2014) melakukan penelitian pengaruh model Problem Based Learning terhadap kemampuan berpikir kreatif pada perguruan tinggi dan didapatkan peningkatan kemampuan berpikir kreatif sesudah model Problem Based Learning digunakan.

Berdasarkan penelitian relevan yang telah dilakukan oleh para peneliti lain maka penelitian ini dilakukan untuk mengetahui efektivitas model Problem Based Learning terhadap Problem Solving Skill siswa kelas XI-MIPA 3 di SMA Negeri 8 Samarinda pada materi Kalor. Peneliti berharap agar hasil dari penelitian ini memberikan dampak terhadap penelitian selanjutnya dalam permasalahan pembelajaran fisika.

\section{METODE}

Jenis penelitian yang digunakan dalam penelitian ini adalah pre-experimental design dengan bentuk One-Group Pretest-Posttest Design.

Penelitian ini dilaksanakan di SMA Negeri 8 Samarinda yang beralamat di Jl. Untung Suropati, Karang Asam Ulu, Kec. Sungai Kunjang, Kota Samarinda, Kalimantan Timur, pada Semester Genap di kelas XI-MIPA 3 Tahun Ajaran 2019/2020. Penelitian ini dilakukan di SMA Negeri 8 Samarinda pada bulan November 2019 Semester Ganjil Tahun Ajaran 2019/2020.

Tes yang digunakan dalam penelitian ini adalah tes pretest-posttest. Soal pretest diberikan pada awal pembelajaran dan soal posttest diberikan pada akhir pembelajaran. Soal pretest dan posttest digunakan untuk 
Efektivitas Model Problem....

mengukur penguasaan konsep siswa pada ranah kognitif dan Problem Solving Skill para peserta didik setelah melalui proses belajar mengajar dengan menggunakan model Problem Based Learning sehingga soal tes akan terdiri dari 2 jenis soal, yaitu soal tes penguasaan konsep siswa dan soal tes Problem Solving Skills siswa. Data diperoleh dengan cara pretest dan posttest secara tertulis dengan 10 soal esai untuk masing-masing tes penguasaan konsep fisika dan Problem Solving Skills siswa sehingga jumlah soal pretest-posttest sebanyak 20 soal esai.

Data yang diperoleh melalui pretest dan posttest yang bertujuan untuk mengetahui tingkat Problem Solving Skill dan Penguasaan Konsep siswa sesudah pembelajaran yang dianalisis melalui: Persentase Hasil Test Problem Solving Skill dan Penguasaan Konsep Siswa, Normalized Gain Problem Solving Skill dan Penguasaan Konsep Siswa, dan Analisis Efektivitas Problem Based Learning terhadap Problem Solving Skill dan Penguasaan Konsep Siswa dengan Uji Paired Sample T-Test.

\section{HASIL DAN PEMBAHASAN}

\section{HASIL}

\section{Pretest dan Posttest Problem Solving} Skill

Persentase secara keseluruhan yang diperoleh dari data hasil pretest dan posttest Problem Solving Skill siswa dapat dilihat pada tabel berikut:

Tabel 1. Distribusi Frekuensi Hasil Pretest dan Posttest Problem Solving Skil

\begin{tabular}{|c|c|c|c|c|c|}
\hline \multirow[b]{2}{*}{ Kategori } & \multirow[b]{2}{*}{ Nilai } & \multicolumn{2}{|c|}{ Pretest } & \multicolumn{2}{|c|}{ Posttest } \\
\hline & & $\begin{array}{l}\text { Jum } \\
\text { lah }\end{array}$ & $\begin{array}{l}\text { Perse } \\
\text { ntase }\end{array}$ & $\begin{array}{l}\text { Jum } \\
\text { lah }\end{array}$ & $\begin{array}{l}\text { Perse } \\
\text { ntase }\end{array}$ \\
\hline $\begin{array}{l}\text { Sangat } \\
\text { Kurang }\end{array}$ & $0-29$ & 14 & $39 \%$ & 0 & $0 \%$ \\
\hline Kurang & $30-59$ & 22 & $61 \%$ & 10 & $28 \%$ \\
\hline Cukup & $60-69$ & 0 & $0 \%$ & 14 & $39 \%$ \\
\hline Baik & $70-79$ & 0 & $0 \%$ & 12 & $33 \%$ \\
\hline $\begin{array}{c}\text { Sangat } \\
\text { Baik }\end{array}$ & $80-100$ & 0 & $0 \%$ & 0 & $0 \%$ \\
\hline \multicolumn{2}{|c|}{ Total } & 36 & $100 \%$ & 36 & $100 \%$ \\
\hline
\end{tabular}

2. Rata-Rata Nilai Pretest dan Posttest Problem Solving Skill

Berdasarkan hasil pretest dan posttest yang diperoleh maka rata-rata hasil penilaian Problem Solving Skill siswa yang diperoleh dari pretest dan posttest dapat dilihat pada tabel berikut:
Tabel 2. Rata-Rata Nilai Pretest dan Posttest Penilaian Problem Solving Skill

\begin{tabular}{ccccc}
\hline Tes & $\begin{array}{c}\text { Nilai } \\
\text { Terendah }\end{array}$ & $\begin{array}{c}\text { Nilai } \\
\text { Tertinggi }\end{array}$ & $\begin{array}{c}\text { Nilai } \\
\text { Rata- } \\
\text { Rata }\end{array}$ & Kategori \\
\hline Pretest & 0 & 50 & 29.3 & $\begin{array}{c}\text { Sangat } \\
\text { Kurang }\end{array}$ \\
\hline Posttest & 32.5 & 76 & 64.42 & Cukup \\
\hline
\end{tabular}

\section{Persentase Indikator Visualisasi/}

\section{Deskripsi Masalah Siswa}

Berdasarkan hasil pretest dan posttest indikator deskripsi masalah yang diperoleh, maka persentase indikator Problem Solving Skill yaitu deskripsi masalah siswa yang diperoleh dari pretest dan posttest dapat dilihat pada tabel berikut:

Tabel 3. Persentase Indikator Visualisasi/ Deskripsi Masalah

\begin{tabular}{cccccc}
\hline \multicolumn{7}{c}{ Kategori } & Nilai & $\begin{array}{c}\text { Jum } \\
\text { lah }\end{array}$ & $\begin{array}{c}\text { Perse } \\
\text { ntase }\end{array}$ & $\begin{array}{c}\text { Jum } \\
\text { lah }\end{array}$ & $\begin{array}{c}\text { Perse } \\
\text { ntase }\end{array}$ \\
\hline $\begin{array}{c}\text { Sangat } \\
\text { Kurang }\end{array}$ & $0-29$ & 9 & $25 \%$ & 0 & $0 \%$ \\
\hline Kurang & $30-59$ & 6 & $17 \%$ & 1 & $3 \%$ \\
\hline Cukup & $60-69$ & 3 & $8 \%$ & 3 & $8 \%$ \\
\hline Baik & $70-79$ & 2 & $6 \%$ & 4 & $11 \%$ \\
\hline $\begin{array}{c}\text { Sangat } \\
\text { Baik }\end{array}$ & $80-100$ & 16 & $44 \%$ & 28 & $78 \%$ \\
\hline \multicolumn{2}{c}{ Total } & 36 & $100 \%$ & 36 & $100 \%$ \\
\hline
\end{tabular}

\section{Persentase Indikator Pendekatan Fisika} Siswa

Persentase indikator Problem Solving Skill yaitu Pendekatan Fisika siswa yang diperoleh dapat dilihat pada tabel berikut:

Tabel 4. Persentase Indikator Pendekatan Fisika

\begin{tabular}{cccccc}
\hline \multirow{2}{*}{ Kategori } & \multirow{2}{*}{ Nilai } & \begin{tabular}{c} 
Pum \\
\cline { 3 - 6 }
\end{tabular} & $\begin{array}{c}\text { Jah } \\
\text { laterse } \\
\text { ntase }\end{array}$ & $\begin{array}{c}\text { Jum } \\
\text { lah }\end{array}$ & $\begin{array}{c}\text { Perse } \\
\text { ntase }\end{array}$ \\
\hline $\begin{array}{c}\text { Sangat } \\
\text { Kurang }\end{array}$ & $0-29$ & 9 & $25 \%$ & 0 & $0 \%$ \\
\hline Kurang & $30-59$ & 4 & $11 \%$ & 1 & $3 \%$ \\
\hline Cukup & $60-69$ & 3 & $8 \%$ & 0 & $0 \%$ \\
\hline Baik & $70-79$ & 2 & $6 \%$ & 3 & $8 \%$ \\
\hline $\begin{array}{c}\text { Sangat } \\
\text { Baik }\end{array}$ & $80-100$ & 18 & $50 \%$ & 32 & $89 \%$ \\
\hline \multicolumn{2}{c}{ Total } & 36 & $100 \%$ & 36 & $100 \%$ \\
\hline
\end{tabular}

\section{Persentase Indikator Aplikasi Khusus Konsep Fisika Siswa}

Persentase indikator Problem Solving Skill yaitu Aplikasi Khusus Konsep Fisika siswa yang diperoleh dapat dilihat pada tabel berikut:

Tabel 5. Persentase Indikator Aplikasi Khusus Konsep Fisika

\begin{tabular}{cccccc}
\hline \multirow{2}{*}{ Kategori } & Nilai & \multicolumn{2}{c}{ Pretest } & \multicolumn{2}{c}{ Posttest } \\
\cline { 3 - 6 } & & lah & $\begin{array}{c}\text { Perse } \\
\text { ntase }\end{array}$ & $\begin{array}{c}\text { Jum } \\
\text { lah }\end{array}$ & $\begin{array}{c}\text { Perse } \\
\text { ntase }\end{array}$ \\
\hline $\begin{array}{l}\text { Sangat } \\
\text { Kurang }\end{array}$ & $0-29$ & 36 & $100 \%$ & 0 & $0 \%$ \\
\hline Kurang & $30-59$ & 0 & $0 \%$ & 9 & $25 \%$ \\
\hline
\end{tabular}


Efektivitas Model Problem....

\begin{tabular}{cccccc}
\hline Cukup & $60-69$ & 0 & $0 \%$ & 4 & $11 \%$ \\
\hline Baik & $70-79$ & 0 & $0 \%$ & 9 & $25 \%$ \\
\hline $\begin{array}{c}\text { Sangat } \\
\text { Baik }\end{array}$ & $80-100$ & 0 & $0 \%$ & 14 & $39 \%$ \\
\hline \multicolumn{2}{c}{ Total } & 36 & $100 \%$ & 36 & $100 \%$ \\
\hline
\end{tabular}

6. Persentase Indikator Prosedur Matematika Siswa

Persentase indikator Problem Solving Skill yaitu Prosedur Matematika siswa yang diperoleh dapat dilihat pada tabel berikut:

Tabel 6. Persentase Indikator Prosedur Matematika

\begin{tabular}{|c|c|c|c|c|c|}
\hline \multirow[b]{2}{*}{ Kategori } & \multirow[b]{2}{*}{ Nilai } & \multicolumn{2}{|c|}{ Pretest } & \multicolumn{2}{|c|}{ Posttest } \\
\hline & & $\begin{array}{c}\text { Jum } \\
\text { lah }\end{array}$ & $\begin{array}{l}\text { Perse } \\
\text { ntase }\end{array}$ & $\begin{array}{l}\text { Jum } \\
\text { lah }\end{array}$ & $\begin{array}{l}\text { Perse } \\
\text { ntase }\end{array}$ \\
\hline $\begin{array}{l}\text { Sangat } \\
\text { Kurang }\end{array}$ & $0-29$ & 36 & $100 \%$ & 0 & $0 \%$ \\
\hline Kurang & $30-59$ & 0 & $0 \%$ & 36 & $100 \%$ \\
\hline Cukup & 60 & 0 & $0 \%$ & 0 & $0 \%$ \\
\hline Baik & $70-79$ & 0 & $0 \%$ & 0 & $0 \%$ \\
\hline $\begin{array}{c}\text { Sangat } \\
\text { Baik }\end{array}$ & 80 & 0 & $0 \%$ & 0 & $0 \%$ \\
\hline
\end{tabular}

\section{Persentase Indikator Kesimpulan Siswa}

Persentase indikator Problem Solving Skill yaitu Kesimpulan siswa yang diperoleh dapat dilihat pada tabel berikut:

Tabel 7. Persentase Indikator Kesimpulan

\begin{tabular}{cccccc}
\hline \multirow{2}{*}{ Kategori } & Nilai & $\begin{array}{c}\text { Pretest } \\
\text { Jum }\end{array}$ & $\begin{array}{c}\text { Perse } \\
\text { ntahe }\end{array}$ & $\begin{array}{c}\text { Jum } \\
\text { lah }\end{array}$ & $\begin{array}{c}\text { Perse } \\
\text { ntase }\end{array}$ \\
\hline $\begin{array}{c}\text { Sangat } \\
\text { Kurang }\end{array}$ & $0-29$ & 36 & $100 \%$ & 0 & $0 \%$ \\
\hline Kurang & $30-59$ & 0 & $0 \%$ & 36 & $100 \%$ \\
\hline Cukup & $60-69$ & 0 & $0 \%$ & 0 & $0 \%$ \\
\hline Baik & $70-79$ & 0 & $0 \%$ & 0 & $0 \%$ \\
\hline $\begin{array}{c}\text { Sangat } \\
\text { Baik }\end{array}$ & $80-100$ & 0 & $0 \%$ & 0 & $0 \%$ \\
\hline \multicolumn{2}{c}{ Total } & 36 & $100 \%$ & 36 & $100 \%$ \\
\hline
\end{tabular}

\section{Rata-Rata Nilai Indikator Problem Solving}

\section{Skill Siswa}

Rata-rata nilai indikator Problem Solving Skill siswa yang diperoleh dari pretest dan posttest dapat dilihat pada tabel berikut:

Tabel 8. Rata-Rata Nilai Indikator Problem Solving Skill

\begin{tabular}{|c|c|c|c|c|}
\hline \multirow[b]{2}{*}{ Indikator } & \multicolumn{2}{|c|}{ Pretest } & \multicolumn{2}{|c|}{ Posttest } \\
\hline & $\begin{array}{l}\text { Rata- } \\
\text { Rata } \\
\text { Nilai }\end{array}$ & Kategori & $\begin{array}{l}\text { Rata- } \\
\text { Rata } \\
\text { Nilai }\end{array}$ & Kategori \\
\hline $\begin{array}{l}\text { Deskripsi } \\
\text { Masalah }\end{array}$ & 57.638 & Kurang & 86.181 & $\begin{array}{l}\text { Sangat } \\
\text { Baik }\end{array}$ \\
\hline $\begin{array}{c}\text { Pendekatan } \\
\text { Fisika }\end{array}$ & 60.833 & Cukup & 91.806 & $\begin{array}{l}\text { Sangat } \\
\text { Baik }\end{array}$ \\
\hline $\begin{array}{c}\text { Konsep } \\
\text { Fisika }\end{array}$ & 11.736 & $\begin{array}{l}\text { Sangat } \\
\text { Kurang }\end{array}$ & 70.069 & Baik \\
\hline $\begin{array}{c}\text { Prosedur } \\
\text { Matematis }\end{array}$ & 8.333 & $\begin{array}{l}\text { Sangat } \\
\text { Kurang }\end{array}$ & 39.514 & Kurang \\
\hline Kesimpulan & 7.986 & $\begin{array}{l}\text { Sangat } \\
\text { Kurang }\end{array}$ & 34.514 & Kurang \\
\hline $\begin{array}{c}\text { Total } \\
\text { Rata-Rata }\end{array}$ & $\begin{array}{c}146.526 \\
29.305\end{array}$ & $\begin{array}{l}\text { Sangat } \\
\text { Kurang }\end{array}$ & $\begin{array}{c}322.084 \\
64.417\end{array}$ & Cukup \\
\hline
\end{tabular}

\section{N-Gain Problem Solving Skill Siswa}

$N$-Gain dapat disajikan pada perolehan data pada tabel berikut:

Tabel 9. N-Gain Problem Solving Skill

\begin{tabular}{cccc}
\hline $\begin{array}{c}\text { Kategori } \\
\text { Nilai } \\
N \text {-Gain }\end{array}$ & Keterangan & $\begin{array}{c}\text { Jumlah } \\
\text { Siswa }\end{array}$ & Presentase \\
\hline$N$-Gain $\leq 0,30$ & Rendah & 6 & $16,667 \%$ \\
\hline $\begin{array}{c}0,30<N \text {-Gain } \\
<0,70\end{array}$ & Sedang & 29 & $80,566 \%$ \\
\hline$N$-Gain $\geq 0,70$ & Tinggi & 1 & $2,778 \%$ \\
\hline
\end{tabular}

\section{Hasil Paired Samples Test Problem} Solving Skill Siswa

Untuk menguji adanya perbedaan yang berarti pada penelitian ini, maka peneliti menggunakan Paired Sample Test pada alat uji IBM SPSS Statistics Subscription. Berdasarkan uji yang dilakukan maka dapat disajikan hasilnya pada tabel berikut:

Tabel 10. Hasil Paired Samples Test Problem Solving Skill

\begin{tabular}{cccc}
\hline & $\mathbf{t}$ & $\mathbf{d f}$ & Sig. (2-tailed) \\
\hline Pretest- & -12.275 & 35 & .000 \\
Posttest & & & \\
\hline
\end{tabular}

\section{N-Gain Problem Solving Skill Siswa}

Persentase secara keseluruhan yang diperoleh dari data hasil pretest dan posttest Problem Solving Skill siswa dapat dilihat pada tabel berikut:

Tabel 11. Distribusi Frekuensi Hasil Pretest dan Posttest Penguasaan Konsep

\begin{tabular}{cccccc}
\hline \multirow{2}{*}{ Kategori } & Nilai & \begin{tabular}{c} 
Pum \\
\cline { 3 - 6 }
\end{tabular} & $\begin{array}{c}\text { lah } \\
\text { ntase }\end{array}$ & $\begin{array}{c}\text { Pum } \\
\text { lah }\end{array}$ & $\begin{array}{c}\text { Perse } \\
\text { ntase }\end{array}$ \\
\hline $\begin{array}{c}\text { Sangat } \\
\text { Kurang }\end{array}$ & $0-29$ & 23 & $64 \%$ & 1 & $3 \%$ \\
\hline Kurang & $30-59$ & 12 & $33 \%$ & 8 & $22 \%$ \\
\hline Cukup & $60-69$ & 1 & $3 \%$ & 10 & $28 \%$ \\
\hline Baik & $70-79$ & 0 & $0 \%$ & 10 & $28 \%$ \\
\hline $\begin{array}{c}\text { Sangat } \\
\text { Baik }\end{array}$ & $80-100$ & 0 & $0 \%$ & 7 & $19 \%$ \\
\hline \multicolumn{2}{c}{ Total } & 36 & $100 \%$ & 36 & $100 \%$ \\
\hline
\end{tabular}

12.Rata-Rata Nilai Pretest dan Posttest Penguasaan Konsep Siswa

Rata-rata hasil penilaian Penguasaan Konsep siswa yang diperoleh dari pretest dan posttest dapat dilihat pada tabel berikut:

Tabel 12. Rata-Rata Nilai Pretest dan Posttest Penilaian Penguasaan Konsep

\begin{tabular}{ccccc}
\hline Tes & $\begin{array}{c}\text { Nilai } \\
\text { Terendah }\end{array}$ & $\begin{array}{c}\text { Nilai } \\
\text { Tertinggi }\end{array}$ & $\begin{array}{c}\text { Nilai } \\
\text { Rata- } \\
\text { Rata }\end{array}$ & Kategori \\
\hline Pretest & 0 & 67 & 24 & $\begin{array}{c}\text { Sangat } \\
\text { Kurang }\end{array}$ \\
\hline Posttest & 25 & 89 & 65.583 & Cukup \\
\hline
\end{tabular}

\section{Hasil Paired Samples Test Penguasaan Konsep Siswa \\ Untuk menguji adanya perbedaan yang}


Efektivitas Model Problem....

berarti pada penelitian ini, maka peneliti menggunakan Paired Sample Test pada alat uji IBM SPSS Statistics Subscription. Berdasarkan uji yang dilakukan maka dapat disajikan hasilnya pada tabel berikut:

Tabel 13. Hasil Paired Samples Test Penguasaan Konsep

\begin{tabular}{cccc}
\multicolumn{4}{c}{ Penguasaan Konsep } \\
\hline & $\mathbf{t}$ & df & Sig. (2-tailed) \\
\hline Pretest- & -13.063 & 35 & .000 \\
Posttest & & 35 & \\
\hline
\end{tabular}

\section{N-Gain Pengusaan Konsep Siswa}

Persentase secara keseluruhan yang diperoleh dari data hasil pretest dan posttest Penguasaan Konsep siswa dapat dilihat pada tabel berikut:

Tabel 14. N-Gain Penguasaan Konsep Siswa

\begin{tabular}{cccc}
\hline $\begin{array}{c}\text { Kategori Nilai } \\
\boldsymbol{N} \text {-Gain }\end{array}$ & Keterangan & $\begin{array}{c}\text { Jumlah } \\
\text { Siswa }\end{array}$ & Presentase \\
\hline$N$-Gain $\leq 0,30$ & Rendah & 5 & $14 \%$ \\
\hline $\begin{array}{c}0,30<N-\text { Gain } \\
<0,70\end{array}$ & Sedang & 24 & $67 \%$ \\
\hline$N-$ Gain $\geq 0,70$ & Tinggi & 7 & $19 \%$ \\
\hline
\end{tabular}

\section{PEMBAHASAN}

Penelitian ini bertujuan untuk mengetahui efektivitas Model Problem Based Learing terhadap Problem Solving Skill siswa dan Penguasaan Konsep siswa kelas XI-MIPA-3 di SMA N 8 Samarinda pada pokok bahasan kalor. Untuk keperluan peneltian, terpilih kelas XIMIPA-3 sebagai sampel penelitian dengan jumlah 34 siswa, yang diberi perlakuan dengan model pembelajaran Problem Based Learning (PBL).

Pada awal penelitian, peneliti menggunakan instrument tes untuk mengukur Problem Solving Skill pada siswa berupa tes yaitu pretest dengan jumlah 10 soal esai. Peneliti juga mengukur Penguasaan Konsep siswa melalui pretest dengan jumlah 10 soal esai yang dapat dilihat pada. Pemberian tes pada awal penelitian merupakan langkah pertama untuk mendapatkan data penelitian.

Setelah dilakukan pretest maka peneliti mengolah hasil tes tersebut, setelah hasil tes tersebut diolah maka peneliti mendapatkan data pretest Problem Solving Skill siswa. Berdasarkan data yang diperoleh, nilai pretest Problem Solving Skill siswa lebih banyak berada pada kategori kurang dan sisanya berada pada kategori sangat kurang, dimana kecenderungannya lebih banyak berada pada kategori kurang. Data yang diperoleh juga menunjukkan bahwa rata-rata nilai Pretest siswa menunjukkan bahwa siswa secara keseluruhan berada pada kategori sangat kurang. Data rata-rata nilai indikator Problem Solving meskipun menunjukkan bahwa indikator
Pendekatan Fisika siswa berada pada kategori cukup, namun siswa secara keseluruhan berada pada kategori sangat kurang. Berdasarkan data-data tersebut dapat dikatakan bahwa Problem Solving Skill siswa kelas XIMIPA-3 masih rendah.

Berdasarkan data yang diperoleh, nilai pretest Penguasaan Konsep siswa lebih banyak berada pada kategori sangat kurang dan sisanya berada pada kategori kurang dan cukup, dimana kecenderungannya lebih banyak berada pada kategori sangat kurang. Data yang diperoleh juga menunjukkan bahwa rata-rata nilai Pretest Penguasaan Konsep siswa menunjukkan bahwa siswa secara keseluruhan berada pada kategori sangat kurang. Berdasarkan data-data tersebut dapat dikatakan bahwa Penguasaan Konsep siswa kelas XIMIPA-3 masih rendah.

Secara khusus peneliti menemukan bahwa pembelajaran yang dilakukan di kelas sebelum dilakukannya penelitian memang masih menggunakan metode tradisional dan praktik atau percobaan yang seharusnya siswa dapat lakukan di pembelajaran tidak terjadi.

Faktor-faktor tersebut akhirnya semakin mendukung penggunaan model Problem Based Learning pada penelitian ini. Sehingga pada proses pembelajaran selama tiga pertemuan di kelas XI-MIPA-3, peneliti menerapkan model Problem Based Learning sesuai dengan langkah-langkah Problem Based Learning. Peneliti menerapkan langkah-langkah model Problem Based Learning di dalam langkahlangkah kegiatan pembelajaran pada setiap Rencana Pelaksanaan Pembelajaran (RPP).

Peneliti yang berperan sebagai guru dalam penelitian ini melakukan pembelajaran dengan langkah kegiatan model Problem Basel Learning $(P B L)$ terdiri dari peneliti mengorientasikan siswa pada masalah, mengorganisasikan siswa untuk belajar, membimbing pengalaman individual/kelompok, mengembangkan dan menyajikan hasil karya, sera menganalisis dan mengevaluasi proses pemecahan masalah.

Pada pertemuan pertama, peneliti memulai pembelajaran dengan langkah Problem Based Learing yaitu mengorientasi siswa pada masalah. Pada langkah ini, peneliti menampilkan permasalahan yang sesuai dengan tujuan pembelajaran dengan memberikan masalah dari video yang ditampilkan dan gambar yang pada Lembar Kerja Peserta Didik (LKPD). Pada LKPD siswa yang merupakan alat bantu dalam pembelajaran pada penelitian ini, juga disusun sesuai dengan langkah model Problem Based Learning. Sehingga pada LKPD, siswa 
diberikan gambar dan penjelasan terkait gambar tersebut yang kemudian akan mengerahkan siswa untuk memberikan identifikasi masalah, dan rumusan masalah. Sehingga tujuan dari langkah orientasi siswa pada masalah pada proses pembelajaran yang juga dibantu dengan alat LKPD ini adalah agar siswa dapat mengetahui masalah apa yang terjadi sehingga diharapkan memberikan efek terhadap indikator Problem Solving Skill siswa yaitu Deskripsi Masalah.

Langkah kedua yaitu mengorganisasikan siswa untuk meneliti. Pada langkah ini, peneliti memberikan penjelasan singkat mengenai materi yang berkaitan dengan permasalahan yang ditampilkan pada langkah sebelumnya, peneliti juga memberikan penjelasan singkat mengenai langkah pengerjaan LKPD, dan kemudian membagi siswa secara perkelompok untuk memasuki langkah model Problem Based Learning selanjutnya. Pada LKPD, siswa yang sudah berada bersama kelompoknya memberikan hipotesis dari masalah yang ada pada LKPD dan mengetahui variabel percobaan serta definisi variabel tersebut dari percobaan yang akan dilakukan. Sehingga tujuan dari langkah mengorganisasikan siswa untuk meneliti ini yang dibantu dengan alat LKPD ini adalah agar siswa dapat bekerja sama sesama kelompoknya, membantu siswa untuk menyelidiki permasalahan bersama-sama, serta membantu siswa untuk merencanakan langkah untuk menyelesaikan masalah sehingga diharapkan memberikan efek terhadap indikator Problem Solving Skill siswa yaitu Pendekatan Fisika.

Langkah ketiga yaitu membimbing penyelidikan siswa secara individu maupun kelompok. Pada langkah ini peneliti membimbing percobaan yang dilakukan siswa bersama kelompoknya, dimana peneliti mengarahkan siswa untuk mengerjakan percobaan sesuai dengan langkah yang terdapat pada LKPD, serta mengarahkan siswa untuk mengerjakan seluruh LKPD. Pada LKPD, siswa bersama kelompoknya melakukan percobaan sesuai dengan rancangan percobaan, mengisi tabel pengamatan, melakukan analisis dari data hasil percobaan, serta membuat kesimpulan berdasarkan percobaan yang dilakukan. Sehingga tujuan dari langkah membimbing penyelidikan ini yang dibantu dengan alat LKPD adalah agar siswa semakin lebih aktif dalam pembelajaran secara berkelompok, semakin aktif dalam memikirkan dan melakukan pemecahan masalah melalui kegiatan penyelidikan dari percobaan yang dilakukan, melakukan perhitungan yang tepat dalam memasukkan data hasil penyelidikan, serta dapat membuat kesimpulan dari percobaan yang dilakukan untuk mengetahui hasil dari penyelesaian masalah yang siswa lakukan. Sehingga diharapkan memberikan efek terhadap indikator Problem Solving Skill siswa yaitu Aplikasi Khusus Konsep Fisika, Prosedur Matematika, dan Kesimpulan.

Langkah keempat yaitu mengembangkan dan menyajikan hasil karya. Pada langkah ini peneliti membimbing siswa untuk mempresentasikan hasil uji coba di kelas sesuai dengan hasil percobaan dan pengerjaan LKPD siswa. Sehingga tujuan dari langkah mengembangkan dan menyajikan hasil karya adalah agar siswa mampu semakin lebih aktif dalam kegiatan pembelajaran.

Langkah kelima yaitu menganalisis dan mengevaluasi proses pemecahan masalah. Pada langkah ini peneliti membantu siswa untuk menganalisis dan mengevaluasi proses siswa selama percobaan atau penyelidikan berlangsung, serta peneliti mendorong siswa untuk dapat menarik kesimpulan pada proses pembelajaran yang telah dilakukan. Peneliti juga memberikan evaluasi terhadap peserta didik untuk membantu siswa memperdalam kemampuan belajar siswa. Sehingga diharapkan juga memberikan efek terhadap seluruh indikator Problem Solving Skill siswa.

Setelah kelima langkah tersebut dilakukan maka pembelajaran pada kelas XI-MIPA-3 pada pertemuan pembelajaran pertama diakhiri. Pada pertemuan pembelajaran kedua dan pembelajaran ketiga, peneliti melakukan langkah yang sama seperti pada pertemuan pembelajaran pertama dengan sub materi kalor yang berbeda. Setelah pertemuan pembelajaran ketiga dilaksanakan, maka pada pertemuan selanjutnya peneliti memberikan posttest Problem Solving Skill dan Penguasaan Konsep siswa yang bentuk dan jumlahnya sama dengan pretest.

Setelah dilakukan tes tersebut maka data tersebut diolah dan peneliti mendapat data posttest Problem Solving Skill siswa seperti pada yang kemudan diolah sehingga didapatkan data. Berdasarkan data yang diperoleh, nilai posttest Problem Solving Skill siswa lebih banyak berada pada kategori cukup dan sisanya berada pada kategori kurang dan baik Selanjutnya berdasarkan data yang diperoleh, mulai dari nilai terendah, nilai tertinggi, dan nilai rata-rata posttest lebih tinggi dibandingkan pretest.

Data rata-rata nilai indikator Problem Solving meskipun menunjukkan bahwa dua indikator yaitu Deskripsi Masalah dan Pendekatan Fisika siswa berada pada kategori sangat baik, namun indikator Prosedur Matematika dan Kesimpulan 
berada pada kategori kurang, dan secara keseluruhan berada pada kategori cukup. Berdasarkan data tersebut dapat dilihat bahwa adanya perbedaan hasil setelah pembelajaran dengan model Problem Based Learning diterapkan. Sehingga secara umum, dapat dikatakan bahwa nilai-nilai tes Problem Solving Skill sesudah Problem Based Learning diterapkan lebih baik dibandingkan ketika sebelum diterapkan pada pembelajaran.

Setelah dilakukan tes Penguasaan Konsep, maka data tersebut diolah dan peneliti mendapat data posttest Penguasaan Konsep siswa yang kemudan diolah sehingga didapatkan data. Berdasarkan data yang diperoleh, nilai posttest Penguasaan Konsep siswa lebih banyak berada pada kategori cukup serta kategori baik dan sisanya berada pada kategori sangat kurang, kurang, dan sangat baik Selanjutnya berdasarkan data yang diperoleh, mulai dari nilai terendah, nilai tertinggi, dan nilai rata-rata posttest lebih tinggi dibandingkan pretest.

Untuk semakin menguatkan penelitian maka peneliti mengolah data pretest dan posttest Problem Solving Skill siswa. Berdasarkan data yang diperoleh, nilai $N$-Gain Problem Solving Skill siswa lebih banyak berada pada kategori sedang dan sisanya berada pada kategori rendah dan tinggi. Dapat terlihat bahwa t-hitung (12.275) lebih besar dibanding dengan t-tabel (2.03011) sehingga Ho ditolak dan $\mathrm{Ha}$ diterima sehingga dapat dikatakan adanya perbedaan yang signifikan antara sebelum model Problem Based Learning diterapkan dan sesudah diterapkan terhadap Problem Solving Skill siswa. Berdasarkan data tersebut, dapat dikatakan adanya efektivitas terhadap Problem Solving Skill siswa setelah model Problem Based Learning diterapkan.

Peneliti juga mengolah data pretest dan posttest Penguasaan Konsep siswa. Berdasarkan data yang diperoleh, nilai $\mathrm{N}$-Gain Penguasaan Konsep siswa lebih banyak berada pada kategori sedang dan sisanya berada pada kategori rendah dan tinggi. Dapat terlihat bahwa t-hitung (13.063) lebih besar dibanding dengan t-tabel (2.03011) sehingga Ho ditolak dan $\mathrm{Ha}$ diterima sehingga dapat dikatakan adanya perbedaan yang signifikan antara sebelum model Problem Based Learning diterapkan dan sesudah diterapkan terhadap Penguasaan Konsep siswa. Berdasarkan data tersebut, dapat dikatakan adanya efektivitas terhadap Penguasaan Konsep siswa setelah model Problem Based Learning diterapkan.

Adanya peningkatan hasil pretest-posttest Problem Solving Skill dan Penguasaan Konsep siswa tidak lepas dari penerapan model pembelajaran Problem Based Learning yang sesuai dengan tujuan dan kelebihannya yaitu dapat menjadikan pembelajaran lebih aktif, meningkatkan keterampilan memecahkan msalah, juga menunjukkan adanya peningkatan dalam prestasi belajar siswa setelah menggunakan model Problem Based Learning. Namun, penelitian ini juga menemukan bahwa masih terdapat kekurangan yang mengakibatkan adanya siswa yang nilai $N$-Gain nya masih berada pada kategori rendah. Hal ini bisa disebabkan beberapa faktor, salah satunya beberapa siswa yang berada dalam kategori tersebut terkadang tidak fokus saat pembelajaran dan peneliti yang kurang mengontrol kondisi di dalam kelas sehingga siswa masih kurang terkontrol, selain itu siswa yang terkadang malas untuk berlatih soal-soal dan waktu penyampaian materi yang relatif sedikit, dimana hal ini memang menjadi salah satu kekurangan model Problem Based Learning. Sehingga pada saat posttest nilai yang dihasilkan tidak jauh berbeda dengan nilai pretest sebelumnya, dan menyebabkan tidak terjadi peningkatan yang lebih.

Demikian model pembelajaran Problem Based Learning dapat memberikan efektivitas terhadap Problem Solving Skill dan Penguasaan Konsep siswa, dimana siswa dalam pembelajaran lebih berorientasi pada masalah melalui percobaan yang dilakukan serta evaluasi yang diberikan. Hal ini didukung oleh kelebihan dari model Problem Based Learning yaitu tidak hanya membantu siswa dalam memperoleh pengetahuan tetapi juga meningkatkan ketrampilan memecahkan masalah, meningkatkan kemampuan belajar mandiri. Sehingga pada penelitian ini, model Problem Based Learning memberikan efektivitas terhadap Problem Solving Skill siswa, hal ini relevan dengan penelitian penelitian Ersoy dan Başer (2013) yang memberikan hasil bahwa model Problem Based Learning memberikan peningkatan kemampuan berpikir kreatif sesudah model Problem Based Learning digunakan. Serta model Problem Based Learning memberikan efektivitas terhadap Penguasaan Konsep siswa, hal ini relevan dengan penelitian penelitian Gurses, Dogar, dan Geyik (2015) yang memberikan hasil bahwa model Problem Based Learning memberikan perbedaan yang signifikan sebelum dan sesudah model Problem Based Learning digunakan.

\section{PENUTUP}


Efektivitas Model Problem....

Berdasarkan hasil analisis data diperoleh kesimpulan sebagai berikut: Efektivitas model Problem Based Learning terhadap Problem Solving Skill siswa dapat terlihat pada rata-rata $\mathrm{N}$-Gain Problem Solving Skill siswa yang diperoleh sebesar 0,480 , serta t-hitung $(12,275)$ lebih besar dibanding dengan t-tabel $(2,0301)$ dan Efektivitas model Problem Based Learning terhadap Penguasaan Konsep siswa dapat terlihat pada rata-rata $\mathrm{N}$-Gain Penguasaan Konsep siswa yang diperoleh sebesar 0,533 , serta t-hitung $(13,063)$ lebih besar dibanding dengan t-tabel (2.0301).

Saran yang dapat peneliti berikan adalah sebagai berikut: Problem Solving Skill siswa dan Penguasaan Konsep siswa akan semakin meningkat dengan menggunakan model Problem Based Learning jika diterapkan secara terus-menerus. Serta, menggunakan penelitian baru yang dapat mengatasi kekurangan model Problem Based Learning untuk meningkatkan Problem Solving Skill dan Penguasaan Konsep siswa.

\section{DAFTAR PUSTAKA}

Coşkun, Y. D., Garipağaoğlu, Ç., \& Tosun, Ü. (2014). Analysis of the Relationship between the Resiliency Level and Problem Solving Skills of University Students. Procedia Social and Behavioral Sciences, 114, 673680.

Elkhamoshi, S. (2011). The effects of modern methods on the stability of achievement in physics of yefren- Libya primary school. Procedia Social and Behavioral Sciences, $12,133-136$.

Ersoy, E., \& Başer, N. (2014). The effects of problem-based learning method in higher education on creative thinking. Procedia Social and Behavioral Sciences, 116, 34943498.

Güneş, İ, Özsoy-Güneş, Z., Derelioğlu, \& Y., Kırbaşlar, F. G. (2015). Relations between operational chemistry and physics problems solving skills and mathematics literacy selfefficacy of engineering faculty students. Procedia - Social and Behavioral Sciences, Vol.174, pp. $457-463$.

Gurses, A., Dogar, C., \& Geyik, E. (2017). Teaching Of The Concept Of Enthalpy Using Problem Based Learning Approach. Procedia - Social and Behavioral Sciences, 197, 2390-2394.
Kabil, O. (2015). Philosopy in Physics Education. Procedia - Social and Behavioral Sciences, 197, 675-679.

Karabacak, K., Nalbant, D., \& Topçuoğlu, P. (2015). Examination of teacher candidates' Problem Solving Skills according to several variables. Procedia - Social and Behavioral Sciences, 174, 3063 - 3071.

Keow, T. N., Subadrah, N., \& Prachak, B. (2014). Developing instruments to measure thinking skills and Problem Solving Skills among Malaysian primary school pupils. Procedia - Social and Behavioral Sciences, 116, $3760-3764$.

Phungsuk, R., Viriyavejakul, C., \& Ratanaolarn, T. (2017). Development of a problem-based learning model via a virtual learning environment. Kasetsart Journal of Social Sciences, 38, 297-306.

Rahono, D., Sunarno, W., \& Cari. (2014). Pembelajaran Fisika dengan Pendekatan Problem Solving Metode Demonstrasi dan Eksperimen untuk Meningkatkan Motivasi dan Hasil Belajar Siswa. Jurnal Inkuiri, Vol.3, No.3, hal 75-85.

Saragih, S., \& Habeahan, W. L. (2014). The Improving of Problem Solving Ability and Students' Creativity Mathematical by Using Problem Based Learning in SMP Negeri 2 Siantar. Journal of Education and Practice, 5 (35), 123-133.

Ulusoy, Y. O., Turan, H., Tanriverdi, B., \& Kolayis, H. (2012). Comparison of perceived Problem Solving Skills of trainee students graduated from different. Procedia - Social and Behavioral Sciences, 46, 2099-2103.

Uzunboylu, H., \& Birinci, C. M. (2014). Assessment Of The Studies On Problem Based Learning Studies. Procedia - Social and Behavioral Sciences, 143, 11920-1199.

Virgana. (2017). Penguasaan Konsep Fisika, Penggunaan Media Musik dan Daya Belajar Siswa. Jurnal Ilmu Pendidikan, Jilid 23, No.1, hlm. 53-59.

Yew, E. H., \& Goh, K. (2016). Problem-Based Learning:An Overview of its Process and Impact. Health Professions Education, Vol.2, pp. 75-79. 